\title{
Orally bioavailable Syk inhibitors with activity in a rat PK/PD model
}

Gebhard Thoma $^{\mathrm{a}, *}$, Siem Veenstra ${ }^{\mathrm{a}}$, Ross Strang ${ }^{\mathrm{a}}$, Joachim Blanz ${ }^{\mathrm{b}}$, Eric Vangrevelinghe ${ }^{\mathrm{a}}$, Joerg Berghausen $^{c}$, Christian C. Lee ${ }^{\mathrm{e}}$, Hans-Günter Zerwes ${ }^{\mathrm{d}}$

${ }^{a}$ Global Discovery Chemistry, ${ }^{b}$ Analytical Sciences \& Imaging, ${ }^{c}$ Metabolism \&

Pharmakokinetics, ${ }^{d}$ Autoimmunity, Transplantation and Inflammation Research, Novartis

Institutes for Biomedical Research, 4056 Basel, Switzerland

${ }^{e}$ Genomics Institute of the Novartis Research Foundation, 10675 John Jay Hopkins Drive, San Diego, CA 92121, USA

* Corresponding author. Tel.; +41 61 3243342; fax: +41 613246735

E-mail address: gebhard.thoma@novartis.com (G. Thoma).

Keywords: Spleen Tyrosine Kinase, Fostamatinib, BIIB-057, GS-9973, Kinase Inhibitors

\begin{abstract}
Design and optimization of benzo- and pyrido-thiazoles/isothiazoles are reported leading to the discovery of the potent, orally bioavailable Syk inhibitor $\mathbf{5}$, which was found to be active in a rat PK/PD model. Compound $\mathbf{5}$ showed acceptable overall kinase selectivity. However, in addition to Syk it also inhibited Aurora kinase in enzymatic and cellular settings leading to findings in the micronucleus assay. As a consequence, compound $\mathbf{5}$ was not further pursued.
\end{abstract}


Spleen Tyrosine Kinase (Syk) is a non-receptor kinase discovered in $1991 .{ }^{1}$ Syk is critical for the transduction of intracellular signal cascades through various immune recognition receptors, such as B cell receptor, Fc receptors, adhesion receptors, or C-type lectin receptors. Following activation Syk phosphorylates a number of substrates and participates in a multi-protein signaling complex, the "signalosome", which leads to the activation of downstream effector pathways such as PKC, MAPK and NFKB. ${ }^{2}$ Syk is an established drug target for autoimmune diseases because aberrant activation of immunoreceptor signaling can contribute to the initiation and progression of chronic inflammation and autoimmunity. ${ }^{3}$

Despite considerable efforts, ${ }^{4}$ only few Syk inhibitors have been evaluated in clinical trials (for structures and data on clinical candidates such as compounds $\mathbf{1}^{5}, \mathbf{2}^{6}$ and $\mathbf{3}^{7}$ see Figure 1 and Table 1). We stopped early work on Syk inhibitors sharing the binding mode of 2 because of insurmountable PK issues. ${ }^{8}$ Furthermore, we had to abandon the promising Syk inhibitor 4 (see Figure 1 and Table 1) due to liver findings and a hERG flag leading to an insufficient therapeutic index for autoimmune indications. ${ }^{9}$ In rat compound 4 exhibited $>100$ fold higher exposure in liver and kidney compared to blood. We hypothesized that the basic, primary amino group required for potency and acceptable PK properties contributed to both the high tissue exposure (volume of distribution was $\mathrm{V}_{\mathrm{ss}}=16.4 \mathrm{~L} / \mathrm{kg}$ ) and the safety issues observed in the toxicity studies. Thus, we set out to identify structurally unrelated back up compounds devoid of an amino group. 

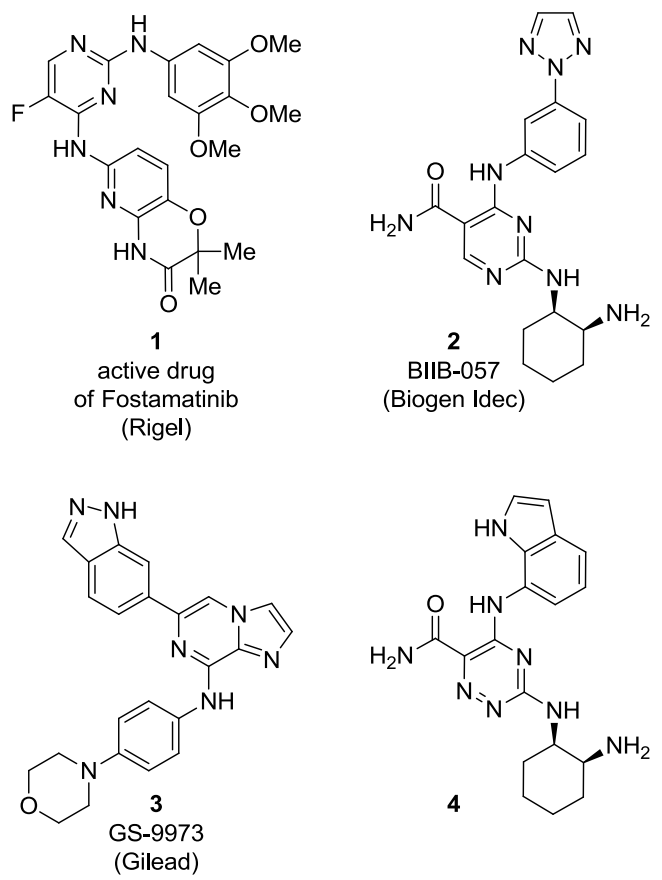

Figure 1. Structures of clinical Syk inhibitors 1-3 and reference compound 4

Table 1. Key in vitro data on reference compounds ${ }^{10}$

\begin{tabular}{|c|c|c|c|c|}
\hline Comp. & $\begin{array}{c}\text { Syk }^{\mathrm{a}} \\
(\text { enzyme) }\end{array}$ & $\begin{array}{c}\text { Kinase }^{\mathrm{b}} \\
\text { selectivity }\end{array}$ & $\begin{array}{c}\text { Syk }^{\mathrm{a}} \\
(\text { cell })\end{array}$ & $\begin{array}{c}\text { Syk }^{\mathrm{a}} \\
\text { (blood) }\end{array}$ \\
\hline $\mathbf{1}$ & $68 \pm 29$ & $18(79)$ & $457 \pm 8$ & $3354 \pm 475$ \\
\hline $\mathbf{2}$ & $13 \pm 4$ & $2(77)$ & $178 \pm 8$ & $952 \pm 70$ \\
\hline $\mathbf{3}$ & $377 \pm 90$ & $0(58)$ & $878 \pm 88$ & $19416 \pm 1474$ \\
\hline $\mathbf{4}$ & $35 \pm 4$ & $0(69)$ & $99 \pm 7$ & $367 \pm 27$ \\
\hline
\end{tabular}

${ }^{\mathrm{a}} \mathrm{IC}_{50}$ in $\mathrm{nM} ; \mathrm{n} \geq 3$ for Syk enzyme, cell and blood assays (SEM shown).

${ }^{\mathrm{b}}$ number of kinases with $\mathrm{IC}_{50}<100 \mathrm{nM}$ in addition to Syk (number of kinases tested). 
Here we disclose the discovery of the potent, orally bioavailable Syk inhibitor $\mathbf{5}$, which is uncharged at physiological $\mathrm{pH}$ and structurally unrelated to 4 . Compound $\mathbf{5}$ did not inhibit the hERG channel $\left(\mathrm{IC}_{50}>30 \mu \mathrm{M}\right)$ and showed substantially reduced tissue exposure compared to 4. Due to good absorption and low in vivo clearance, compound $\mathbf{5}$ exhibited favorable PK properties in rat and was active in a rat PK/PD model. Unfortunately, compound $\mathbf{5}$ could not be further pursued because in addition to Syk it also inhibited Aurora kinase in enzymatic and cellular settings leading to findings in the micronucleus assay.

A structure of the early, moderately active Boehringer Ingelheim Syk inhibitor $\mathbf{6}^{11}$ bound to Syk kinase domain solved at Novartis revealed that the nitrogen in the 1-position of the 1,6naphthyridine core and the adjacent sp2-carbon form H-bonds with the hinge sequence of Syk (Figure 2A, Table 2). ${ }^{12}$ Recently, the Boehringer group has shown that the basic amine of 6 can be replaced with neutral groups, such as lactams and aromatic amides, leading to more potent analogues. ${ }^{13}$ To mimic the binding mode of $\mathbf{6}$, we decided to explore benzo- and pyrido-thiazole cores as novel hinge binding motifs and prepared a set of neutral pilot compounds 7-10 lacking the basic amine of $\mathbf{6}$ (Table 2; for the syntheses of 7-10 see Schemes 1-4). ${ }^{14}$ 

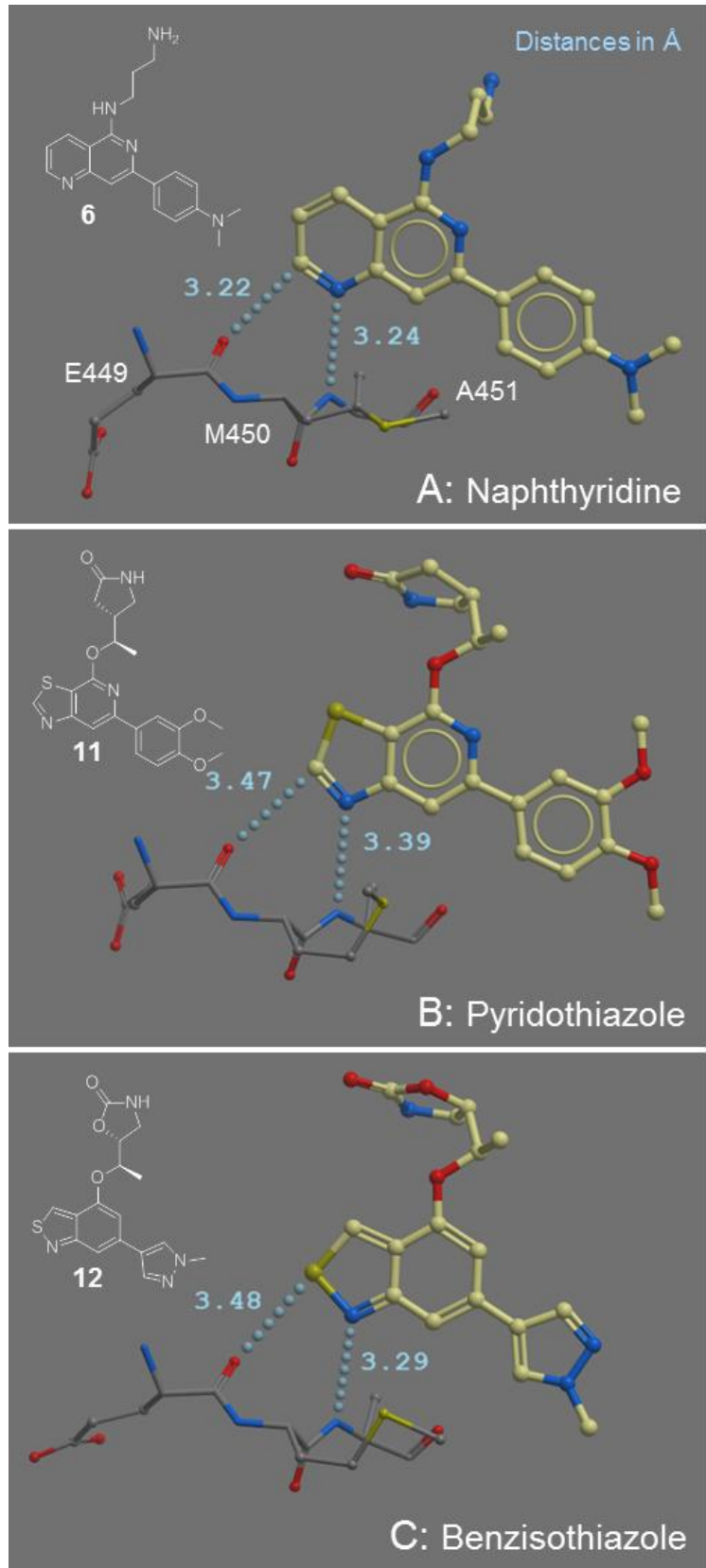

Figure 2. Crystal structures of 6, 11 and $\mathbf{1 2}$ bound to Syk kinase domain (H-bonds with hinge sequence E449-M450-A451 shown) ${ }^{12}$ 
Table 2. Key in vitro data ${ }^{10}$ and rat PK parameters

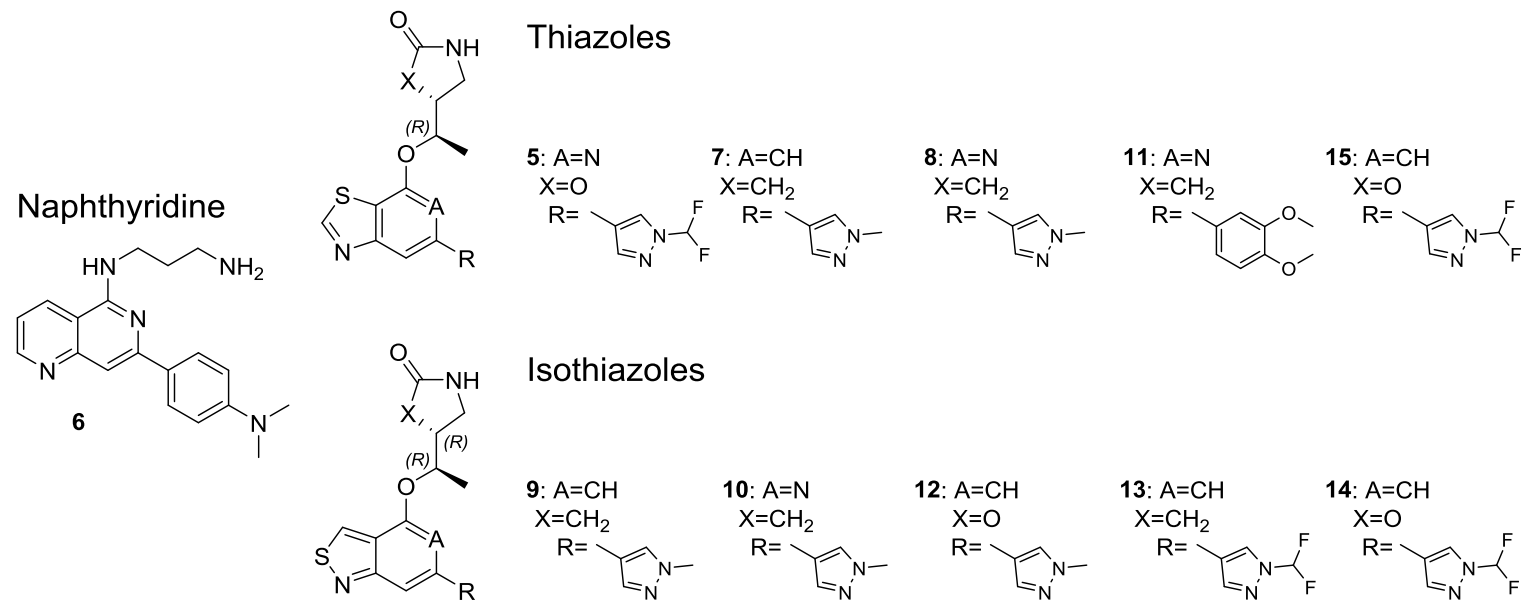

\begin{tabular}{|c|c|c|c|c|c|c|c|c|c|c|}
\hline Comp. & $\begin{array}{c}\text { Syk }^{\mathrm{a}} \\
\text { (enzyme) }\end{array}$ & $\begin{array}{c}\text { Kinase }^{\mathrm{b}} \\
\text { selectivity }\end{array}$ & $\begin{array}{l}\text { Syk }^{\mathrm{a}} \\
\text { (cell) }\end{array}$ & $\begin{array}{c}\text { Syk }^{\mathrm{a}} \\
\text { (blood) }\end{array}$ & $\begin{array}{c}\mathrm{CL}^{\mathrm{c}} \\
(\mathrm{mL} / \mathrm{min} \mathrm{kg})\end{array}$ & $\begin{array}{l}\mathrm{Vss}^{\mathrm{c}} \\
(\mathrm{L} / \mathrm{kg})\end{array}$ & $\begin{array}{l}\text { MRT }^{c} \\
\text { (h) }\end{array}$ & $\begin{array}{c}\mathrm{AUC}^{\mathrm{c}, \mathrm{d}} \\
\text { i.v. }\left(\mathrm{nM}^{*} \mathrm{~h}\right)\end{array}$ & $\begin{array}{l}\mathrm{BAV}^{\mathrm{c}} \\
(\%)\end{array}$ & $\begin{array}{l}\mathrm{C}_{\max }{ }^{\mathrm{c}, \mathrm{d}} \\
(\mathrm{nM})\end{array}$ \\
\hline 4 & $35 \pm 4$ & $0(69)$ & $99 \pm 7$ & $367 \pm 27$ & 31 & 16.4 & 8.7 & 1'449 & 60 & 80 \\
\hline 5 & $38 \pm 15$ & $1(60)$ & $284 \pm 20$ & $522 \pm 37$ & 4 & 1.3 & 6.0 & $14^{\prime} 791$ & 88 & 917 \\
\hline 6 & $552 \pm 150$ & $0(86)$ & $951 \pm 234$ & n.t. & n.t. & n.t. & n.t. & n.t. & n.t. & n.t. \\
\hline 7 & $33 \pm 24$ & $4(40)$ & $89 \pm 34$ & $186 \pm 31$ & n.t. & n.t. & n.t. & n.t. & n.t. & n.t. \\
\hline 8 & $26 \pm 5$ & $0(61)$ & $284 \pm 20$ & $538 \pm 157$ & 54 & 2.3 & 0.7 & 951 & 46 & 103 \\
\hline 9 & $46 \pm 8$ & $2(63)$ & $161 \pm 52$ & $298 \pm 43$ & 45 & 2.4 & 0.9 & $1^{\prime} 056$ & 30 & 94 \\
\hline 10 & $40(n=1)$ & $0(20)$ & $247(n=1)$ & $290 \pm 49$ & 86 & 2.4 & 0.5 & 577 & 27 & 109 \\
\hline 11 & $5 \pm 2$ & $4(66)$ & $132 \pm 19$ & $517 \pm 95$ & 53 & 1.2 & 0.4 & 858 & 35 & 178 \\
\hline 12 & $16 \pm 3$ & $7(60)$ & $166 \pm 69$ & $737 \pm 116$ & 12 & 1.5 & 2.0 & 3887 & 100 & 477 \\
\hline 13 & $57 \pm 9$ & $0(54)$ & $340 \pm 31$ & $1018 \pm 407$ & 18 & 2.8 & 2.6 & 2341 & 100 & 263 \\
\hline 14 & $16 \pm 2$ & $5(60)$ & $328 \pm 87$ & $197 \pm 38$ & 7 & 1.4 & 2.8 & 5,440 & 100 & 614 \\
\hline 15 & $9 \pm 9$ & $11(60)$ & $107 \pm 8$ & $230 \pm 51$ & 5 & 1.3 & 4.7 & $10^{\prime} 142$ & 91 & 803 \\
\hline
\end{tabular}

${ }^{\mathrm{a}} \mathrm{IC}_{50}$ in $\mathrm{nM} ; \mathrm{n} \geq 3$ for Syk enzyme, cell and blood assays (SEM shown).

${ }^{\mathrm{b}}$ Number of kinases with $\mathrm{IC}_{50}<100 \mathrm{nM}$ in addition to Syk (number of kinases tested).

${ }^{\mathrm{c}}$ Cassette dosing in Sprague Dawley rats; i.v. $1 \mathrm{mg} / \mathrm{kg}$, NMP:PEG200 (3:7); p.o. 3 mg/kg, CMC:water:tween (0.5:99:0.5), d Dose normalized. 
We were pleased to learn that these compounds are equipotent to our development candidate 4 in enzymatic, cellular and blood assays (Table 2). ${ }^{10}$ Notably, thiazoles $(\mathbf{7}, \mathbf{8})$ and isothiazoles $(\mathbf{9}, \mathbf{1 0})$ were equally active. We obtained crystal structures of representative compounds $\mathbf{1 1}$ (thiazole; Table 2; for the synthesis see Scheme 2) and 12 (isothiazole; Table 2; for the synthesis see Scheme 3) bound to Syk kinase domain, which confirmed our binding hypothesis indicating that the novel sulfur containing thiazole and isothiazole scaffolds are bioisosteres of 1,6naphthyridine (Figure $2 \mathrm{~B}$ and C). Similarly to $\mathbf{6}$, the thiazole $\mathbf{1 1}$ forms two H-bonds with the hinge sequence of Syk. Isothiazole 12 cannot form the second H-bond; however, this is compensated for by a favorable interaction between sulfur and the backbone carbonyl oxygen of E449. ${ }^{15}$

Compounds 7-10 exhibited good solubility (> $1 \mathrm{mM}$ at pH 6.8), medium permeability (log PAMPA from -4.9 to $-5.210^{-6} \mathrm{~cm} / \mathrm{s}$ ), medium plasma protein binding (human: $80-90 \%$ ) and acceptable stability against rat liver microsomes (half-life from 34-82 min). In vivo rat PK studies revealed medium to high clearance $(\mathrm{CL}=45-86 \mathrm{~mL} / \mathrm{min} \mathrm{kg})$, low volumes of distribution $\left(\mathrm{V}_{\mathrm{ss}} \sim\right.$ $2 \mathrm{~L} / \mathrm{kg}$ ) and short mean residence times (MRT $<1 \mathrm{~h})$ for all three series tested (Table 2). The medium to high clearance and the short MRT were confirmed in dog PK studies.

To identify metabolic weak spots we investigated the metabolism of representative compounds from all four sulfur containing scaffolds in human and rat liver microsomes. Independent of the nature of the bicyclic core similar metabolites were observed across species mainly affecting the pyrazole (hydroxylation, N-demethylation) and the lactam substituent (hydroxylation). However, in contrast to the thiazoles, the isothiazoles formed trace quantities of glutathione conjugates indicating the formation of reactive intermediates. Their molecular masses pointed to an 
unexpected metabolic pathway involving addition of both $\mathrm{GSH}$ and $\mathrm{H}_{2} \mathrm{O}$. The trace quantities prevented us from isolation and structure elucidation. As a consequence, we decided not to consider the isothiazoles for the selection of potential development compounds.

However, we used the benzisothiazole core for the rapid optimization of the PK properties. Replacement of the pyrazole by aryl and 5 or 6-ring heteroaryl groups did not lead to derivatives with reduced in vivo clearance. In addition, the favorable physicochemical properties were compromised. Thus, we explored differently substituted pyrazoles and found the difluoromethyl derivative 13 to show improved PK properties (Table 2; for the synthesis see Scheme 3). However, the potency was limited. In efforts to reduce the hydroxylation of the lactam residue we introduced an isosteric cyclic carbamate (for the synthesis of the building block see Scheme 5). Compound 12 and its lactam analog $\mathbf{9}$ showed similar potencies as well as similar key interactions of lactam and cyclic carbamate with the enzyme (Figure 3). The carbonyl oxygen and the ring nitrogen form H-bonds with K402 and S511, whereas beneficial van der Waals contacts were observed between the methyl group and G378 and V385. These lipophilic interactions along with an improved pre-organization of the bioactive conformation might explain that related compounds lacking the methyl group were substantially less active. 


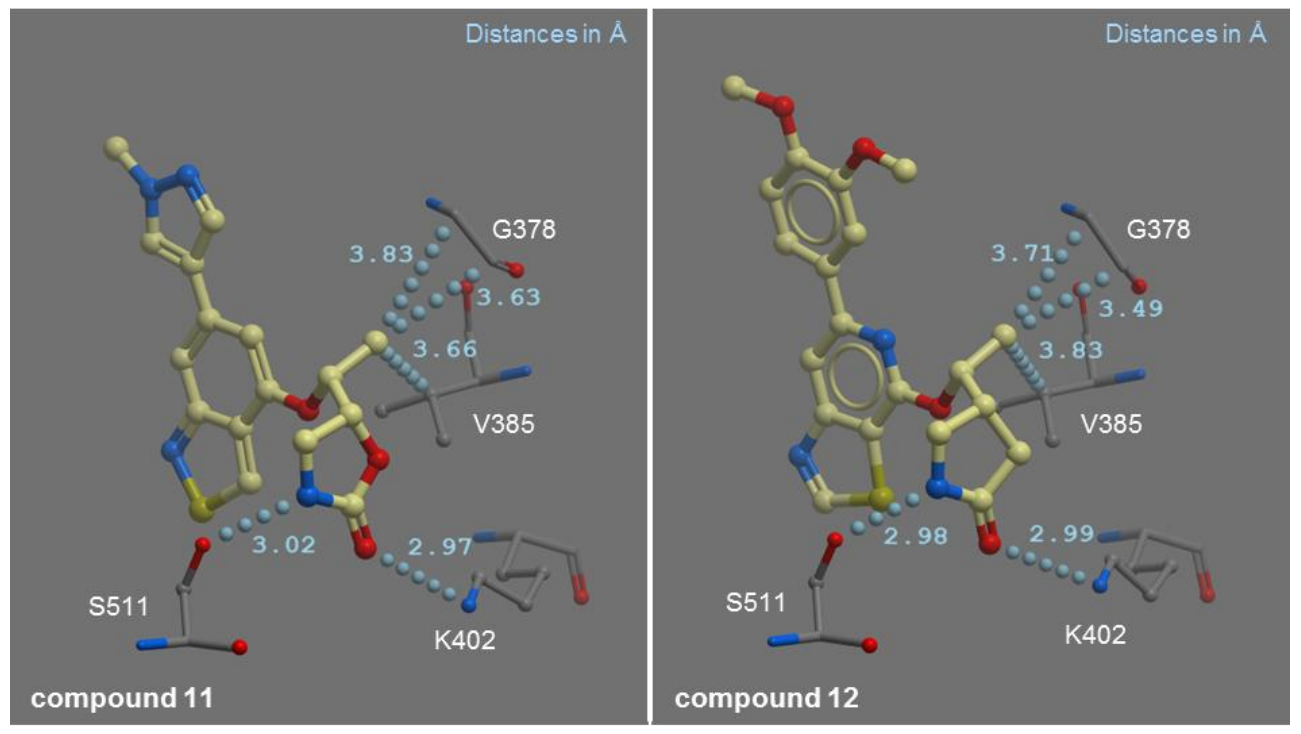

Figure 3. Crystal structures of $\mathbf{1 1}$ and $\mathbf{1 2}$ bound to Syk kinase domain (Key interactions of lactam and cyclic carbamate shown; H-bonds with K402 and S511as well as van der Waals contacts with G378 and V385) $)^{12}$

Carbamate 12 showed improved PK properties compared to its lactam analog 9 (Table 2; for the synthesis see Scheme 3). However, the MRT of $2 \mathrm{~h}$ and the kinase selectivity were suboptimal. Combination of difluoromethylpyrazole and carbamate led to compound 14 (Table 2; for the synthesis see Scheme 3) with promising PK properties, low clearance, good potency but limited kinase selectivity. Next we transferred the learnings to the thiazole series and prepared $\mathbf{5}$ and $\mathbf{1 5}$ (Table 2; for the syntheses see Schemes 2 and 1, respectively). Both compounds exhibited low clearance, good MRT and promising AUC. Because of its superior kinase selectivity we selected 5 for further profiling against the abandoned development candidate 4.

Compound 5 showed $\mathrm{IC}_{50}$ values above $30 \mu \mathrm{M}$ in both hERG binding and automated patch clamp assays. Compound $\mathbf{4}$ did not exhibit substantial hERG channel inhibition in a manual patch clamp assay at $30 \mu \mathrm{M}$ and showed an $\mathrm{IC}_{50}$ value of $28 \mu \mathrm{M}$ in an automated patch clamp assay; however, 
under GLP conditions, an $\mathrm{IC}_{50}$ value of $5 \mu \mathrm{M}$ was established. ${ }^{9}$ Thus, the predictability of the in vitro assays can be challenged, but based on the available data the neutral compound $\mathbf{5}$ appeared promising.

Table 3. Distribution of compounds 4 and 5 in different matrices following $1 \mathrm{mg} / \mathrm{kg}$ i.v. administration in rat

\begin{tabular}{|c|c|c|}
\hline Matrix & $\mathbf{4}$ & $\mathbf{5}$ \\
\hline Blood (ng/g) & 41 & 1014 \\
\hline Liver (ng/g) & 9175 & 2134 \\
\hline Kidney (ng/g) & 3866 & 1433 \\
\hline
\end{tabular}

The PK parameters of $\mathbf{4}$ and $\mathbf{5}$ differed substantially probably due to the absence of a basic amine in 5 (Table 2). Compound 4 exhibited medium clearance and a very high $\mathrm{V}_{\mathrm{ss}}$ leading to a long MRT of $8.7 \mathrm{~h}$ while compound $\mathbf{5}$ showed a low Vss and a low clearance also resulting in a long MRT of $6 \mathrm{~h}$. In line with the distinct $\mathrm{V}_{\mathrm{ss}}$, the compounds showed very different distribution profiles in rat. Comparable concentrations in blood, liver and kidney were observed for $\mathbf{5}$, whereas compound 4 showed 100-200 fold increased concentrations in tissue (Table 3). In light of the liver findings observed with $\mathbf{4}$, we considered the PK profile of 5 to be more desirable. Compound 5 was tested in our rat PK/PD model (Figure 4). ${ }^{9}$ Following oral administration, blood samples were taken at different times for PK determination as well as assessment of inhibition of Syk-dependent signaling events. For this, the extent of SLP76 phosphorylation in monocytes in response to stimulation by anti CD32 was quantified. A dose of $3 \mathrm{mg} / \mathrm{kg}$ of 5 led to 78, 79 and 60 
$\%$ inhibition after 2, 4 and $8 \mathrm{~h}$ post administration, respectively. No inhibition was observed after 24 h. Blood concentrations were 1930, 1341, 827 and $40 \mathrm{nM}$, respectively. The low exposure after $24 \mathrm{~h}$ was unexpected based on the PK profile (Table 2). A potential explanation is the usage of different rat strains for PK experiment (Sprague Dawley) and PK/PD model (Lewis). Due to the limited AUC of compound 5 (10-fold lower), higher doses were required to achieve substantial inhibition in this model. However, the effects seen with $\mathbf{5}$ were more sustained. ${ }^{9}$

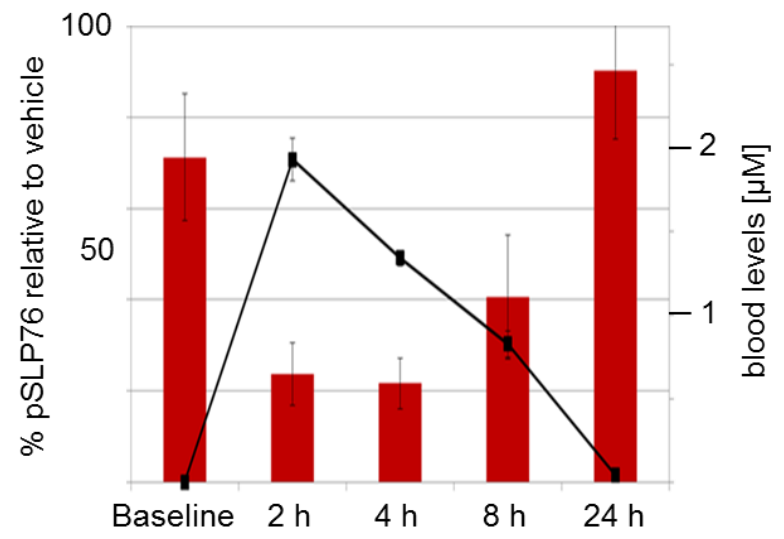

Figure 4. PK/PD experiments with compound 5 (3 mg/kg, p.o.). Single dose treatment of Lewis rats followed by ex-vivo assessment of blood compound levels (PK) and Fc $\gamma$ R-induced P-SLP76 in peripheral blood monocytes (PD). Bars=\% pSLP76; Line= blood levels.

Compound 5 showed acceptable overall kinase selectivity (Table 2). However, in addition to Syk it also inhibited Aurora $\mathrm{A}$ in our enzymatic assay $\left(\mathrm{IC}_{50}=57 \mathrm{nM}\right) .{ }^{16}$ Unfortunately, this was confirmed in a cellular Aurora B assay $\left(\mathrm{IC}_{50}=110 \mathrm{nM}\right) .{ }^{17}$ The compound was negative in the Ames test but positive in the micronucleus assay. This was not unexpected as Aurora A inhibition causes micronuclei formation and aneuploidy, Aurora B inhibition results in a cytokinesis defect 
leading to binucleate cells, and inactivation of both Aurora A and B causes an abrogation in chromosome segregation and mitotic exit with a single quadroploid nucleus. ${ }^{18}$

We have described the optimization of novel benzo- and pyrido-thiazoles/isothiazoles leading to the discovery of the potent, orally bioavailable Syk inhibitor $\mathbf{5}$, which was found to be active in a rat PK/PD model. However, as a consequence of findings in the micronucleus assay, compound $\mathbf{5}$ was not further pursued. 

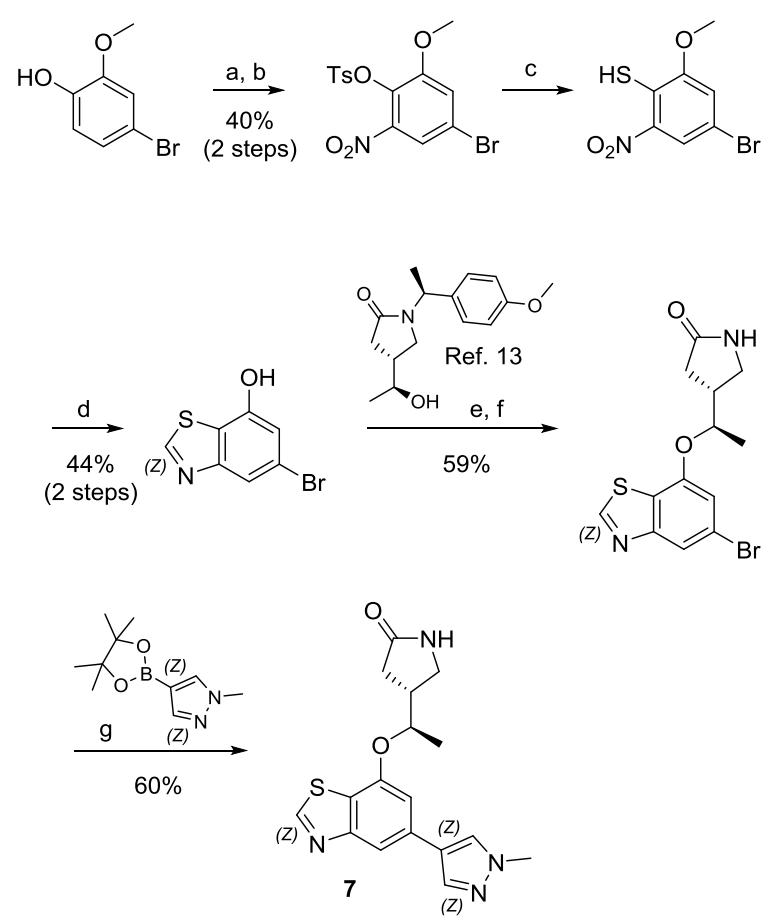

Scheme 1. Synthesis of 7 (15 prepared similarly). Reagents and conditions: (a) $\mathrm{HNO}_{3}$, $\mathrm{CH}_{3} \mathrm{CO}_{2} \mathrm{H},-10^{\circ} \mathrm{C} \rightarrow 25^{\circ} \mathrm{C}, 1 \mathrm{~h}$; (b) $\mathrm{TsCl}$ (1.2 equiv.), pyridine (2.0 equiv.), $\mathrm{CH}_{2} \mathrm{Cl}_{2}, 0^{0} \mathrm{C} \rightarrow$ $25^{\circ} \mathrm{C}, 16 \mathrm{~h}$; (c) $\mathrm{Na}_{2} \mathrm{~S} \times 9 \mathrm{H}_{2} \mathrm{O}$ (2.0 equiv.), DMF, $0^{\circ} \mathrm{C}, 1 \mathrm{~h}$; (d) $\mathrm{Zn}$ powder (5.0 equiv.), HCOOH, reflux, $16 \mathrm{~h}$; (e) alcohol ${ }^{13}$ (1.1 equiv.), $\left(t-\mathrm{BuO}_{2} \mathrm{C}\right){ }_{2} \mathrm{~N}_{2}$ (2.0 equiv.), $\mathrm{PPh}_{3}$ (2.0 equiv.), $\mathrm{CH}_{2} \mathrm{Cl}_{2}$, $25^{\circ} \mathrm{C}, 1 \mathrm{~h}$; (f) TFA, microwave, $100^{\circ} \mathrm{C}, 20 \mathrm{~min}$; (g) boronate ester (3.0 equiv.), $\mathrm{Pd}\left(\mathrm{PPh}_{3}\right)_{2} \mathrm{Cl}_{2}(0.1$ equiv.), $\mathrm{Na}_{2} \mathrm{CO}_{3}$ (3.0 equiv.), dioxane, $100^{\circ} \mathrm{C}, 16 \mathrm{~h}$. 

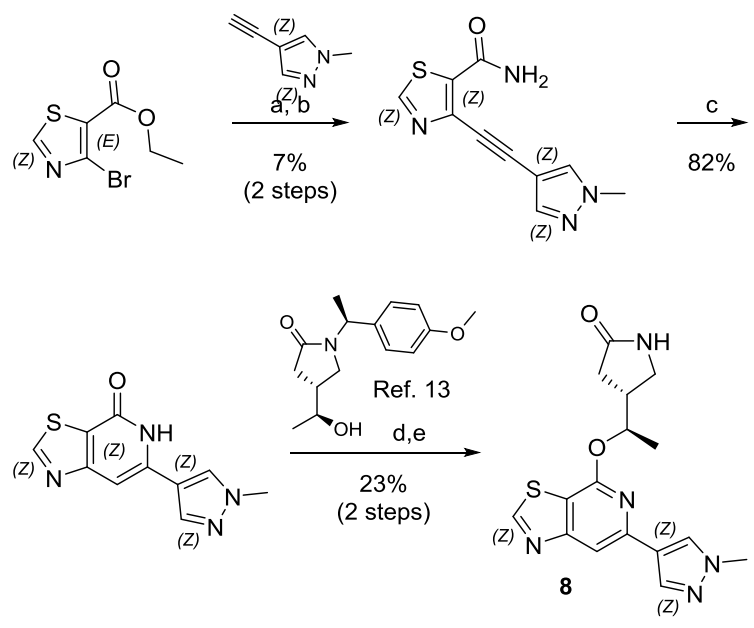

Scheme 2. Synthesis of $\mathbf{8}(\mathbf{5}, 11$ prepared similarly). Reagents and conditions: (a) $\mathrm{RC} \equiv \mathrm{CH}(1.5$ equiv.), $\mathrm{CuI}$ (0.05 equiv.), $\mathrm{Pd}\left(\mathrm{PPh}_{3}\right)_{4}$ (0.07 equiv.), $\mathrm{NEt}_{3}$ (3.0 equiv.), $\mathrm{DMF}, 70^{0} \mathrm{C}, 0.5 \mathrm{~h}$; (b) $\mathrm{NH}_{3}$ (12 equiv.), $\mathrm{MeOH}, 70^{\circ} \mathrm{C}, 16 \mathrm{~h}$; (c) $\mathrm{NaO} t \mathrm{Bu}$ (1.4 equiv.), THF, $70^{\circ} \mathrm{C}, 1 \mathrm{~h}$; (d) alcohol (1.8 equiv.), ( $t$ - $\left.\mathrm{BuO}_{2} \mathrm{C}\right){ }_{2} \mathrm{~N}_{2}$ (2.2 equiv.), $\mathrm{PPh}_{3}$ (2.2 equiv.), $\mathrm{CH}_{2} \mathrm{Cl}_{2}, 25^{\circ} \mathrm{C}, 2 \mathrm{~h}$; (d) TFA, $100^{\circ} \mathrm{C}, 15$ $\min$. 

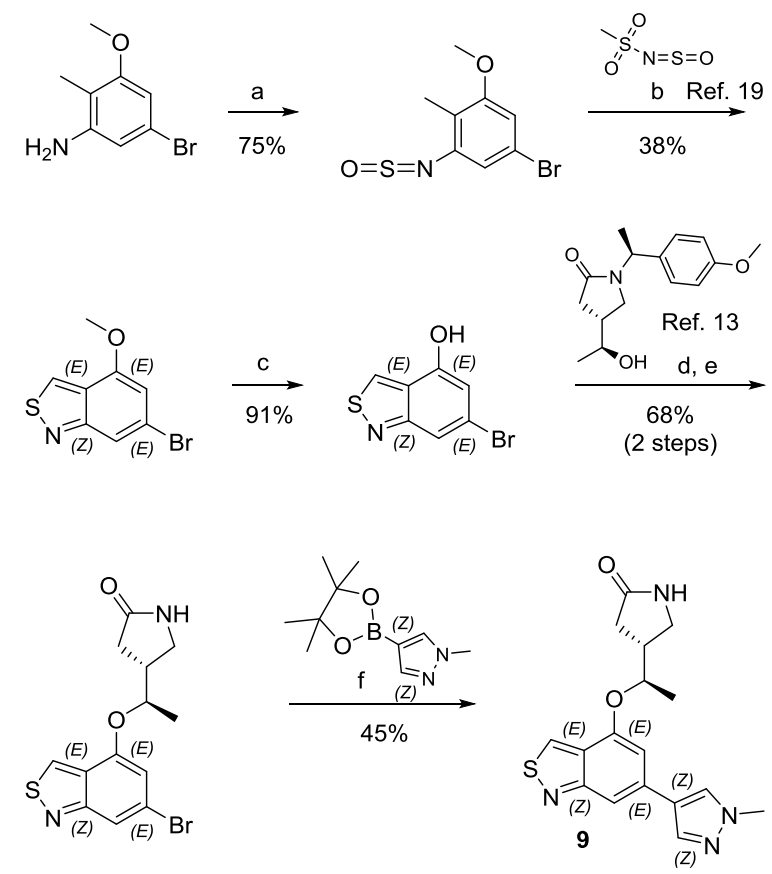

Scheme 3. Synthesis of $9\left(\mathbf{1 2}, \mathbf{1 3}, 14\right.$ prepared similarly). Reagents and conditions: (a) $\mathrm{SOCl}_{2}$ (2.0 equiv.), benzene, reflux, $18 \mathrm{~h}$; (b) $\mathrm{N}$-sulfinyl-methanesulfonamide ${ }^{19}$ (1.6 equiv.), pyridine (1.1 equiv.), benzene, reflux, $24 \mathrm{~h}$; (c) $48 \%$ aq. $\mathrm{HBr}, 140^{\circ} \mathrm{C}, 2.5 \mathrm{~h}$; (d) alcohol (1.0 equiv.), ( $t$ $\left.\mathrm{BuO}_{2} \mathrm{C}\right){ }_{2} \mathrm{~N}_{2}$ (1.5 equiv.), $\mathrm{PPh}_{3}$ (1.5 equiv.), THF, $0 \rightarrow 25^{\circ} \mathrm{C}, 16 \mathrm{~h}$; (e) TFA, $80^{\circ} \mathrm{C}, 3.5 \mathrm{~h}$; (f) boronate (1.5 equiv.), $\mathrm{Pd}(\mathrm{DTBPF}) \mathrm{Cl}_{2}$ (0.06 equiv.), $\mathrm{K}_{3} \mathrm{PO}_{4}$ (2.0 equiv.), Tol/EtOH/H2O (7/2/1), $100^{\circ} \mathrm{C}, 1 \mathrm{~h}$. 

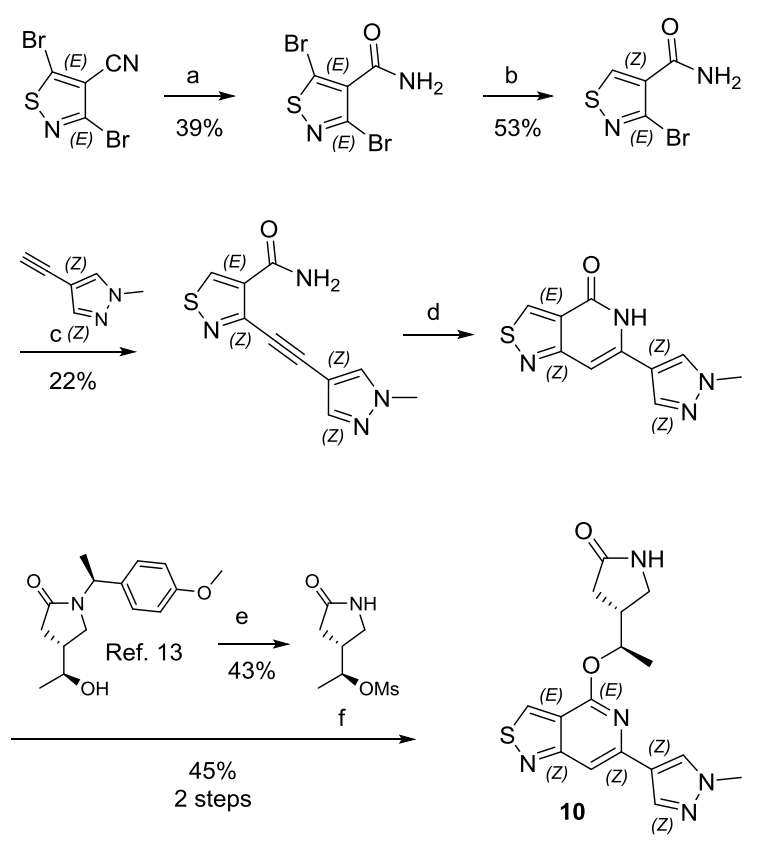

Scheme 4. Synthesis of 10. Reagents and conditions: (a) $\mathrm{H}_{2} \mathrm{SO}_{4}$ (conc.), $25^{\circ} \mathrm{C}, 72 \mathrm{~h}$; (b) $\mathrm{Zn}$ powder (5.0 equiv.), $\mathrm{MeOH} / \mathrm{HCOOH}(1.3 / 1), 10^{\circ} \mathrm{C}, 2$ h; (c) $\mathrm{RC} \equiv \mathrm{CH}$ (1.4 equiv.), $\mathrm{CuI}(0.07$ equiv.), $\mathrm{Pd}\left(\mathrm{PPh}_{3}\right)_{4}$ (0.1 equiv.), $\mathrm{NEt}_{3}$ (3.0 equiv.), $\mathrm{DMF}, 70^{\circ} \mathrm{C}, 0.5 \mathrm{~h}$; (d) $\mathrm{NaO} t \mathrm{Bu}$ (2.1 equiv.), DMF/THF, $70^{\circ} \mathrm{C}, 0.5 \mathrm{~h}$; (e) 1 . TFA, microwave, $100^{\circ} \mathrm{C}, 14 \mathrm{~min} ; 2 . \mathrm{MsCl}$ (0.9 equiv.), $\mathrm{NEt}_{3}$ (2.7 equiv.), $\mathrm{CH}_{2} \mathrm{Cl}_{2}, 0 \rightarrow 25^{\circ} \mathrm{C}, 1 \mathrm{~h}$; (f) mesylate (2.0 equiv.), $\mathrm{K}_{2} \mathrm{CO}_{3}$ (3.0 equiv.), DMF, microwave, $140^{\circ} \mathrm{C}, 0.5 \mathrm{~h}$. 

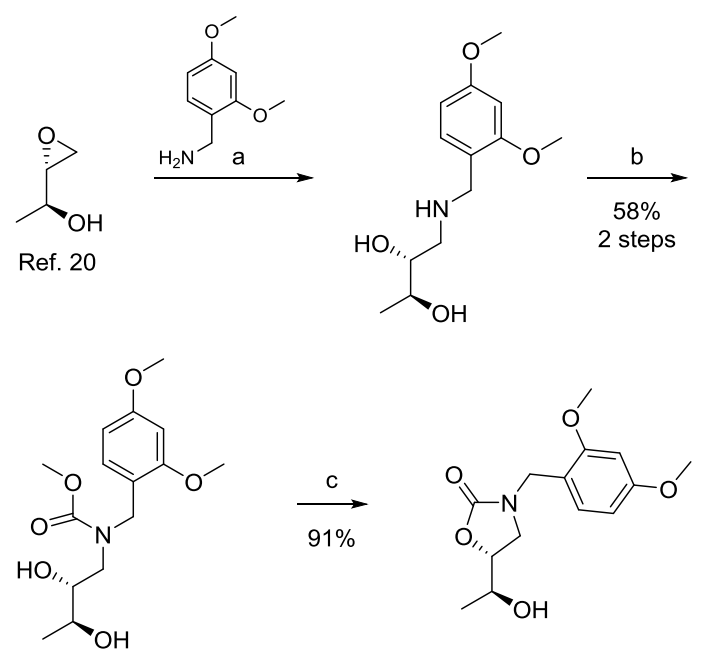

Scheme 5. Synthesis of the protected (hydroxyethyl)oxazolidinone. Reagents and conditions. (a) Amine (1.3 equiv.), EtOH, 60 h, $25^{\circ} \mathrm{C}$; (b) $\mathrm{Na}_{2} \mathrm{CO}_{3}$ (2.5 equiv.), $\mathrm{ClCO}_{2} \mathrm{Me} 1.2$ equiv.), $\mathrm{CH}_{2} \mathrm{Cl}_{2} /$ $\mathrm{H}_{2} \mathrm{O}(2.5 / 3.0), 5 \rightarrow 25^{\circ} \mathrm{C}, 3 \mathrm{~h}$; (c) $\mathrm{NaOMe}$ (2.5 equiv.), $\mathrm{MeOH}$, reflux, $40 \mathrm{~min}$.

\section{Acknowledgment}

We gratefully acknowledge the expert assistance of Valerie Caballero, Thierry Délémonté, MuYun Gao, Joanna Grant, Alice Hauchard, Anne-Marie Jutzi, Alexandre Luneau, Patric Neubert, Kenneth Ng, Jürg Peter, Marc Schäfer, Jennifer Shaffer and Phuoc Thanh Thai. We thank Reiner Aichholz and Hong Liu for helpful discussions. The structural work in this paper is based on experiments conducted at beamline 5.0.3 of the Advanced Light Source (ALS). The ALS is supported by the Director, Office of Science, Office of Basic Energy Sciences, Material Sciences Division of the US Department of Energy under contract DE-AC03-76SF00098 at Lawrence Berkeley National Laboratory. 


\section{References and notes}

1. Taniguchi, T.; Kobayashi, T.; Kondo, J.; T., Kazuhiro; Nakamura, H.; Suzuki, J.; Nagai, K.; Yamada, T.; Nakamura, S.; Yamamura, H. J. Bio. Chem. 1991, 266, 15790-15796.

2. (a) Mócsai, A.; Ruland, J.; Tybulewicz, V. L. J. Nat. Rev. Immunol. 2010, 10, 387; (b) Kulathu, Y.; Grothe, G.; Reth, M. Immunol. Rev. 2009, 232, 286; (c) Gilfillan, A. M.; Rivera, J. Immunol. Rev. 2009, 228, 149; (d) Geahlen, R. L. Biochim. Biophys. Acta 2009, 1793, 1115; (e) Koretzky, G. A.; Abtahian, F. Silverman, M. A. Nat. Rev. Immunol. 2006, $6,67$.

3. (a) Bajpai, M.; Chopra, P.; Dastidar, S. G.; Ray, A. Expert Opi. Investig. Drugs, 2008, 17, 641; (b) Siraganian, R. P.; Zhang, J.; Suzuki, K.; Sada, K. Mol. Immunol. 2002, 38, 1229; (c) Wong, B. R.; Grossbard, E. B.; Payan, D. G.; Masuda, E. S. Expert Opi. Invest. Drugs 2004, 13, 743; (d) Ghosh, D.; Tsokos, G. C. Autoimmunity, 2010, 43, 48; (e) Lucas, M. C.; Tan, S.-L. Future Med. Chem. 2014, 6, 1811.

4. (a) Singh, R.; Masuda, E. S.; Payan, D. G. Discovery and Development of Spleen Tyrosine Kinase (SYK) Inhibitors. J. Med. Chem. 2012, 55, 3614; (b) Moore, W. J.; Richard, D.; Thorarensen, A. Expert Opin. Ther. Patents 2010, 20, 1703; (c) Norman, P. Expert Opin. Ther. Patents 2014, 24, 573; (d) Castillo, M.; Forns, P.; Erra, M.; Mir, M.; Lopez, M.; Maldonado, M.; Orellana, A.; Carreno, C.; Ramis, I.; Miralpeix, M.; Vidal, B. Bioorg. Med. Chem. Lett. 2012, 22, 5419; (e) Forns, P.; Esteve, C.; Taboada, L.; Alonso, J. A.; Orellana, A.; Maldonado, M.; Carreno, C.; Ramis, I.; Lopez, M.; Miralpeix, M.; Vidal, B. Bioorg. Med. Chem. Lett. 2012, 22, 2784; (f) Lucas, M. C.; Goldstein, D. M.; Hermann, J. C.; Kuglstatter, A.; Liu, W.; Luk, K. C.; Padilla, F.; Slade, M.; Villasenor, A. G.; Wanner, J.; Xie, W.; Zhang, X.; Liao, C. J. Med. Chem. 2012, 55, 10414; (g) Padilla, 
F.; Bhagirath, N.; Chen, S.; Chiao, E.; Goldstein, D. M.; Hermann, J. C.; Hsu, J.;

Kennedy-Smith, J. J.; Kuglstatter, A.; Liao, C.; Liu, W.; Lowrie, L. E., Jr.; Luk, K. C.;

Lynch, S. M.; Menke, J.; Niu, L.; Owens, T. D.; O-Yang, C.; Railkar, A.; Schoenfeld, R.

C.; Slade, M.; Steiner, S.; Tan, Y.-C.; Villasenor, A. G.; Wang, C.; Wanner, J.; Xie, W.;

Xu, D.; Zhang, X.; Zhou, M.; Lucas, M. C. J. Med. Chem. 2013, 56, 1677; (h) Lucas, M.

C.; Bhagirath, N.; Chiao, E.; Goldstein, D. M.; Hermann, J.; Hsu, P.-Y.; Kirchner, S.;

Kennedy-Smith, J.: Kuglstatter, A.; Lukacs, C.; Menke, J.; Niu, L.; Padilla, F.; Peng, Y.;

Polonchuk, L.; Railkar, A.; Slade, M.; Soth, M.; Xu, D.; Yadava, P.; Yee, C.; Zhou, M.;

Liao, C. J. Med. Chem. 2014, 57, 2683; (i) Liddle, J.; Atkinson, F. L.; Barker, M. D.;

Carter, P. S.; Curtis, N. R.; Davis, R. P.; Douault, C.; Dickson, M. C.; Elwes, D.; Garton, N. S.; Gray, M.; Hayhow, T. G.; Hobbs, C. I.; Jones, E.; Leach, S.; Leavens, K.; Lewis, H. D.; McCleary, S.; Neu, M.; Patel, V. K.; Preston, A. G. S.; Ramirez-Molina, C.;

Shipley, T. J.; Skone, P. A.; Smithers, N.; Somers, D. O.; Walker, A. L.; Watson, R. J.;

Weingarten, G. G. Bioorg. Med. Chem. Lett. 2011, 21, 6188; (j) Moy, L. Y.; Jia, Y.;

Caniga, M.; Lieber, G.; Gil, M.; Fernandez, X.; Sirkowski, E.; Miller, R.; Alexander, J.

P.; Lee, H.-H.; Shin, J. D.; Ellis, J. M.; Chen, H.; Wilhelm, A.; Yu, H.; Vincent, S.;

Chapman, R. W.; Kelly, N.; Hickey, E.; Abraham, W. M.; Northrup, A.; Miller, T.;

Houshyar, H.; Crackower, M. A. Am. J. Respir. Cell Mol. Biol. 2013, 49, 1085; (k)

Brazeau, J.-F. ; Rosse, G. ACS Med. Chem. Lett. 2014, 5, 278; (1) Ellis, J. M.; Altman, M.

D.; Bass, A.; Butcher, J. W.; Byford, A. J.; Donofrio, A.; Galloway, S.; Haidle, A. M.;

Jewell, J.; Kelly, N.; Leccese, E. K.; Lee, S.; Maddess, M.; Miller, J. R.; Moy, L. Y.;

Osimboni, E.; Otte, R. D.; Reddy, M. V.; Spencer, K.; Sun, B.; Vincent, S. H.; Ward, G.

J.; Woo, G. H. C.; Yang, C.; Houshyar, H.; Northrup, A. B. J. Med. Chem. 2015, 58, $1929 ;(\mathrm{m})$ 
5. (a) Argade, A.; Bhamidipati, S.; Li, H.; Sylvain, C.; Clough, J.; Carroll, D.; Keim, H.; Braselmann, S.; Taylor, V.; Zhao, H.; Herlaar, E.; Issakani, S. D.; Wong, B. R.; Masuda, E. S.; Payan, D. G.; Singh, R. Bioorg. Med. Chem. Lett. 2015, 25, 2122; (b) Braselmann, S.; Taylor, V.; Zhao, H.; Wang, S.; Sylvain, C.; Baluom, M.; Qu, K.; Herlaar, E.; Lau, A.; Young, C.; Brian R. Wong, Lovell, S.; Sun, T.; Park, G.; Argade, A.; Jurcevic, S.; Pine, P.; Singh, R.; Grossbard, E. B.; Payan, D. G.; Masuda, E. S. J. Pharm. Exp. Ther. 2006, 319, 998; (c) Weinblatt, M. E; Kavanaugh, A.; Burgos-Vargas, R.; Dikranian, A. H.; Medrano-Ramirez, G.; Morales-Torres, J. L.; Frederick T. Murphy, F. T.; Musser, T. K.; Straniero, N.; Vicente-Gonzales, A. V.; Grossbard, E. Arthristis Rheumatism 2008, 58, 2209. For a more comprehensive analysis of the kinase selectivity of $\mathbf{1}$ see Davis, M. I.; Hunt, J. P.; Herrgard, S.; Ciceri, P.; Wodicka, L. M.; Pallares, G.; Hocker, M.; Treiber, D. K.; Patrick P Zarrinkar, P. P. Nat. Biotech. 2011, 29, 1046. For the discontinuation of 1 in rheumatoid arthritis see http://clinicaltrials.gov/show/NCT01264770.

6. Coffey, G.; DeGuzman, F.; Inagaki, M.; Pak, Y.; Delaney, S. M.; Ives, D.; Betz, A.; Jia, Z. J.; Pandey, A.; Baker, D.; Hollenbach, S. J.; Phillips, D. R.; Uma Sinha, U. J. Pharm. Exp. Ther. 2012, 340, 350. For the withdrawal of a planned phase II trial in rheumatoid arthritis see http://www.clinicaltrials.gov/ct2/show/NCT01652937?term=biib$\underline{057 \& \text { rank }=1}$

7. Currie, K. S.; Kropf, J. E.; Lee, T.; Blomgren, P.; Xu, J.; Zhao, Z.; Gallion, S.; Whitney, J. A.; Maclin, D.; Lansdon, E. B.; Maciejewski, P.; Rossi, A. M.; Rong, H.; Macaluso, J.; Barbosa, J.; Di Paolo, J. A.; Mitchell, S. A. J. Med. Chem. 2014, 57, 3856. 
8. Thoma, G.; Blanz, J.; Buhlmayer, P.; Druckes, P.; Kittelmann, M.; Smith, A. B.; van Eis, M.; Vangrevelinghe, E.; Zerwes, H.-G.; Che, J.; He, X.; Jin, Y.; Lee, C. C.; Michellys, P.Y.; Uno, T.; Liu, H. Bioorg. Med. Chem. Lett. 2014, 24, 2278.

9. Thoma, G.; Smith, A. B.; van Eis, M. J.; Vangrevelinghe, E.; Blanz, J.; Aichholz, R.; Littlewood-Evans, A.; Lee, C. C.; Liu, H.; Zerwes, H.-G. J. Med. Chem. 2015, 58, 1950.

10. Potency and kinase selectivity of Syk inhibitors were assessed in enzymatic assays based on the Caliper microfluidic mobility shift technology. Cellular activity was measured in Ramos B-cells upon BCR stimulation with anti-IgM which leads to phosphorylation of the adaptor protein BLNK (B cell linker protein), a direct Syk substrate. Inhibition of Syk in presence of $90 \%$ human blood was monitored in monocytes following Fc $\gamma \mathrm{R}$ stimulation with an anti CD32 antibody. This leads to the phosphorylation of the adaptor protein SLP-76 which is also a direct substrate of Syk. For details on the assays see Ref. 9.

11. Cywin, C. L.; Zhao, B.-P.; McNeil, D. W.; Hrapchak, M.; Prokopowicz, A. S.; Goldberg, D. R.; Morwick, T. M.; Gao, A.; Jakes, S.; Kashem, M.; Magolda, R. L.; Soll, R. M.; Player, M. R.; Bobko, M. A.; Rinker, J.; DesJarlais, R. L.; Winters, M. P. Bioorg. Med. Chem. Lett. 2003, 13, 1415.

12. Structures deposited in the RCSB Protein Data Bank under PDB ID: 5CXZ (6), PDB ID: 5CXH (11) and PDB ID: 5CY3 (12).

13. (a) Fiegen, D.; Handschuh, S.; Hobbie, S.; Hoffmann, M.; Kono, T.; Sato, Y.; Schnapp, A.; Schuler-Metz, A. PCT Int. Appl. WO 2010015518; (b) Bouyssou, T.; Dahmann, G.; Engelhardt, H.; Fiegen, D.; Handschuh, S.; Hobbie, S.; Hoffmann, M.; Kono, T.; Reiser, U.; Sato, Y.; Schnapp, A.; Schuler-Metz, A. PCT Int. Appl. WO 2010015520; (c) Hoffmann, M.; Dahmann, G.; Fiegen, D.; Handschuh, S.; Klicic, J.; Linz, G.; Schaenzle, 
G.; Schnapp, A.; East, S. P.; Mazanetz, M.P.; Scott, J.; Walker, Edward PCT Int. Appl. WO 2011092128; (d) Hoffmann, M.; Bischoff, D.; Dahmann, G.; Klicic, J.; Schaenzle, G.; Wollin, S. L. M.; Convers-Reignier, S. G.; East, S. P.; Marlin, F. J.; McCarthy, C.; Scott, J. PCT Int. Appl. WO 2013014060.

14. We also explored benzo[c] $[1,2,5]$ thiadiazoles and $[1,2,5]$ thiadiazolo[3,4-c]pyridines but the corresponding analogs were found to be less potent. Only the R,R-configuration of the chiral lactam residue led to highly active compounds.

15. Beno,B. R.; Yeung,K.-S.; Bartberger, M. D.; Pennington,L. D.; Meanwell, N. A. J. Med. Chem. 2015, 58, 4383.

16. Compounds 7, 11, 12, 14 and 15 also inhibited Aurora A with $\mathrm{IC}_{50}$ values of $\leq 100 \mathrm{nM}$. Compounds 9 and 10 were less potrnt showing $\mathrm{IC}_{50}$ values of 576 and $800 \mathrm{nM}$, respectively.

17. The Aurora B cell assay was performed by ProQinase GmbH, Freiburg, Germany; http://proqinase.com/

18. Hochegger, H.; Hegarat, N.; Pereira-Leal, J. B. Open Biol. 2013, 3, 120185.

19. Singerman, G. M. J. Het. Chem., 1975, 12, 877.

20. Trost, B. M.; Ball, Z. T.; Laemmerhold, K. M. J. Am. Chem. Soc. 2005, 127, 100028. 


\section{Graphical abstract}

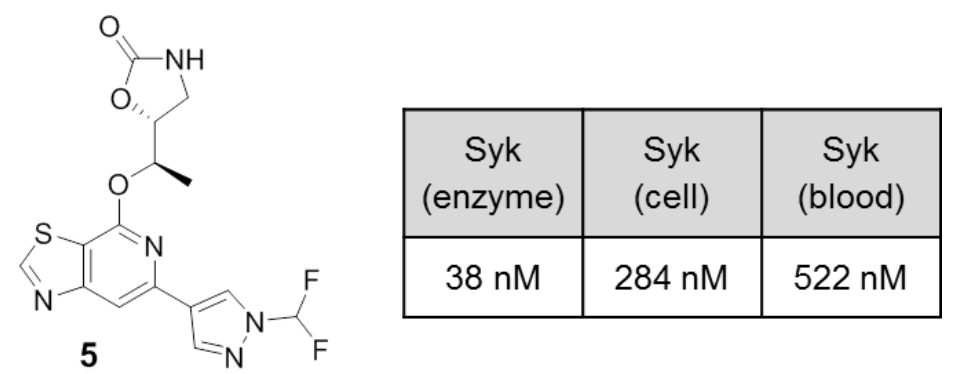

